\title{
DAVID \& GOLIATH: HOW YOUNG COMPETITION AGENCIES CAN SUCCEED IN FIGHTING CROSS-BORDER CARTELS
}

\author{
Pierre M. Horna ${ }^{1}$
}

\begin{abstract}
:
How can small and young agencies cope and target cross border cartels? This paper explores the related challenges and puts forward a pragmatic tool to break down international cooperation barriers. Given the efforts of the ICN in seeking ways and means to operationalise cross-border cooperation in investigation of cases as well as those of selected UNCTAD member States in trying to trigger the international measures section of the UN Set on Competition, this brief contribution attempts to strengthen the ICN framework for non-confidential information sharing between competition agencies by incorporating specific key elements that are provided by the section F.4 related to voluntary consultations so as to address effectively the harmful effects of international cartels in emerging markets.
\end{abstract}

Keywords: competition, international cooperation, United Nations, voluntary consultations, sharing of non-confidential information

JEL codes: K21, K33, K39

\footnotetext{
${ }^{1}$ Visiting research fellow at the University of Oxford Centre for Competition Law and Policy and Legal affairs official at the Competition and Consumer Policies Branch of the United Nations Conference on Trade and Development (UNCTAD). First, special thanks to Professor Ariel Ezrachi, Director of the Oxford's Centre for Competition Law and Policy. Thanks for valuable suggestions and ideas are due to Paulo Burnier Da Silveira, Antonio Capobianco, Luis Guzmán, Scott Hammond and Saadaki Suwasono. Thanks for detailed and valuable feedback to earlier versions of this working paper to David Anderson, Russell Damtoft, Fernando Furlan, Anna Pozdnyakova and two anonymous reviewers. The views expressed and remaining errors are the author's responsibility and are not to be taken as the official views of the UNCTAD Secretariat or its Member States.
} 


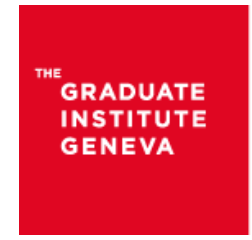

\section{Centre for Trade and Economic Integration (CTEI)}

The Centre for Trade and Economic Integration fosters world-class multidisciplinary scholarship aimed at developing solutions to problems facing the international trade system and economic integration more generally. It works in association with public sector and private sector actors, giving special prominence to Geneva-based International Organisations such as the WTO and UNCTAD. The Centre also bridges gaps between the scholarly and policymaking communities through outreach and training activities in Geneva.

www.graduateinstitute.ch/ctei 


\section{Introduction}

During the period 2000-2016, 75 new cartels were uncovered each year and more than 100,000 companies (7200 named) were found liable for international price fixing whereby gross cartels overcharges exceed USD 1.5 trillion, $60 \%$ by global cartels. ${ }^{2}$ Despite the staggering number of discoveries, it is believed that a great number of cross-border cartels remain undetected. Those cartels that are documented have brought about tremendous damage to economies, particularly to emerging markets. The effects on developing countries are particularly pronounced with these countries importing in billions in goods from industries that had seen a price-fixing conspiracy. ${ }^{3}$ These imports represented $6.7 \%$ of imports and $1.2 \%$ of gross domestic product (GDP) in developing countries. For the poorest developing countries, they represented an even larger proportion of trade, namely $8.8 \%$ of imports ${ }^{4}$, thereby limiting their benefits from international trade and access to global supply chains ${ }^{5}$. The actual effect on developing countries may be more profound, considering that the foregoing figures suffer from a downward bias as they pertain only to discovered international cartels and cover the effects of only that one anti-competitive practice. ${ }^{6}$ Global or multinational cartels can make substantial profits worldwide even if they are sanctioned and punished by mature jurisdictions; thereby the deterrent effect of bigger fines would be insufficient. ${ }^{7}$

At the same time, cooperation among competition authorities has increased and intensified over the past 15 years $^{8}$, especially in the form of informal cooperation in policy and investigative matters. In addition, technical assistance ${ }^{9}$ has led to sharing of experiences in all regions of the world and the

\footnotetext{
${ }^{2}$ See Connor, John M., "The Private International Cartels (PIC) Data Set: Guide and Summary Statistics, 1990- July 2016 (revised $2^{\text {nd }}$ Edition),", USA, (2016); Connor, John M. "Global antitrust prosecutions of modern international cartels." Journal of Industry, Competition and Trade 4.3 (2004): 239-267 and Connor, John M. "Effectiveness of antitrust sanctions on modern international cartels." Journal of Industry, Competition and Trade 6.3-4 (2006): 195-223. .

${ }^{3}$ See Levenstein, M. and Suslow, V. "Private International Cartels and their Effect on Developing Countries" Background Paper for the World Bank's World Development Report 2001, World Bank, Washington DC, (2001) and Clarke, Julian L., and Simon J. Evenett. "The deterrent effects of national anticartel laws: evidence from the international vitamins cartel." The antitrust bulletin 48.3 (2003): 689-726.

${ }^{4}$ Levenstein, M. and Suslow, V. Supra at Note 3.

5 See Gerber, David J., Competition Law and Global Supply Chains (June 16, 2016). Available at SSRN: https://ssrn.com/abstract=2807154

${ }^{6}$ Besides price-fixing, anticompetitive practices take the form, inter alia, of import cartels, abuses of dominance and mergers and acquisitions with anticompetitive effects in the markets of other countries. For a study of the common objectives and elements of competition laws, see Noonan, Chris, "The Emerging Principles of International Competition Law", International Economic Law, Oxford University Press, Oxford UK, (2008). pp.59-68.

${ }^{7}$ Michaels, Ralf. "Supplanting Foreign Antitrust." Law and Contemporary Problems 79.4 (2016): at p. 236.

${ }^{8}$ For instance, two recent international cases reported by US underscored the depth and breadth of US cooperation with foreign competition agencies: (1) Staples/Office Depot matter, whereby cooperation with Australia, Canada, and the European Union took place. Even US and Canada filed complaints “... to block the transaction in court on the same day...”; and (2) GSK/Novartis where cooperation with Australia, Canada, the European Union, New Zealand as well as Pakistan and Ukraine took place. Tritell, Randolph, and Elizabeth Kraus. "The Federal Trade Commission's International Antitrust Program." (2016) at p. 5.

${ }^{9}$ Consider the example of Latin America. See Alvarez, Ana Maria; Horna, Pierre. "Implementing Competition Law and Policy in Latin America: The Role of Technical Assistance." Chicago-Kent Law Review 83.1 (2008): 91-128.
} 
enactment of domestic competition laws. ${ }^{10}$ To date, 139 countries worldwide ${ }^{11}$ count with competition laws and with its respective agencies and therefore the complexity of modern competition law requires the adaption of old instruments with newer ones such as referrals to private international law solutions for global competition problems. ${ }^{12}$ More advanced agencies have also found ways to cooperate in investigations in worldwide cartel investigations. ${ }^{13}$ Many countries that have entered into trade agreements have introduced competition provisions in in South-South and North-South RTAs ${ }^{14}$. Although some of these agreements have a good level of detail in the type of conducts that would be considered anti-competitive, and some of them even create a regional authority to investigate and issue binding resolutions ${ }^{15}$, there is still a long way to $\mathrm{go}^{16}$.

To date, there are important efforts on international cooperation at the multilateral level between international organizations, such as the Organization for Economic Cooperation and Development $(\mathrm{OECD})^{17}$, the United Nations Conference on Trade and Development (UNCTAD) ${ }^{18}$, and successful international networks of competition agencies, such as the International Competition Network

${ }^{10}$ For a comprehensive assessment see: Terhechte, Jörg Philipp. International competition enforcement law between cooperation and convergence. Springer Science \& Business Media, 2011. And Terhechte, Jörg Philipp. "“Cooperation" as Guiding Principle of International Competition Enforcement Law." International Competition Enforcement Law Between Cooperation and Convergence. Springer Berlin Heidelberg, 2011. 9-21.

${ }^{11}$ Fox, Eleanor M. "Competition Policy: The Comparative Advantage of Developing Countries." Law and Contemporary Problems 79.4 (2016): 69-84. At p. 79 citing Aydin, Umut, and Tim Büthe. "Success and Limits of Competition Law \& Policy in Developing Coutries: Explaining Variations in Outcomes; Exploring Possibilities and Limits." Paper for the Kenan/Rethinking Regulation Workshop, Duke University, 2015.

${ }^{12}$ See Danov, Mihail. "Global competition law framework: A private international law solution needed." Journal of Private International Law 12.1 (2016): 77-105

${ }^{13}$ The past decade has been dominated by several major cross-border cartel investigations of alleged price fixing in major industries, including air cargo, freight forwarding, thin film transistor liquid crystal display (TFT/LCD) panels, and, most recently, auto parts. US has reported that cooperation with Australia, Belgium,Brazil, Canada, China, the European Union, Japan, Korea, Mexico, New Zealand, Pakistan, South Africa, Taiwan, Ukraine, and the United Kingdom has been carried out during the fiscal year 2015. TRITELL, Supra note 8 at p. 4. For more information see U.S. Submission to the OECD Working Party on Co-operation and Enforcement "Discussion on International Cooperation," June 8, 2012

${ }^{14}$ See Alvarez, Ana María, Julian Clarke, and Verónica Silva. "Lessons from the negotiation and enforcement of competition provisions in South-South and North-South RTAs." Competition provisions in regional trade agreements: how to assure development gains (2005): 123

${ }^{15}$ Do, Kim Them. "Bad Problem Getting Worse: Regional Trade Agreements and the Future of the Multilateral Framework on Competition Policy and Law." (2011).

${ }^{16}$ Jenny, Frédéric, and Pierre M. Horna. "Modernization of the European system of competition law enforcement: Lessons for other regional groupings." Competition Provisions in Regional Trade Agreements: How to Assure Development Gains (2005): 281.

${ }^{17}$ See the recent work of OECD on international cooperation: International Co-operation- Stocktaking exercise of the Competition Committee's Past work (WP3) (June 2012); Limitations and constraints to International Co-operation (WP3) (October 2012); Discussion on International Co-operation (WP3); Report on OECD/ICN Survey on Intl Enforcement Cooperation; Improving international co-operation in cartel investigations (GFC) (February 2013); Discussion on International Co-operation (WP3) (June 2013); Remedies in Cross-Border Merger cases (WP3) \& Discussion on Possible Amendments to the 1995 Recommendation on International Co-operation (October 2013); New Recommendation on International Cooperation (September 2014). See www.oecd.org/competition/

${ }^{18}$ See the recent work of UNCTAD on international cooperation: (1) "Cross-border anticompetitive practices: The challenges for developing countries and economies in transition". 19 April 2012. TD/B/C.I/CLP/16; (2) "Modalities and procedures for international cooperation in competition cases involving more than one country". 26 April 2013. TD/B/C.I/CLP/21; (3) "The impact of cartels on the poor" 24 July 2013. TD/B/C.I/CLP/24/Rev.1; (4) "Informal cooperation among competition agencies in specific cases". 28 April 2014. TD/B/C.I/CLP/29: and (5) "International cooperation in merger cases as a tool for effective enforcement of competition law". 27 April 2015. TD/RBP/CONF.8/4. See www.unctad.org/competition/ 
(ICN). ${ }^{19}$ And yet, in practice, these efforts have not always translated into effective collaboration, in particular when small economies and agencies are involved.

This paper explores the challenges to better collaboration in the collaborative quest against cartel activity. It considers the ICN framework and its application to date and reflects on the possibility of strengthening its impact. It suggests the use of some elements of Section F.4 of the UN Set on Competition and the ability to weave them into the ICN framework. Although, this could be arguable it can provide the necessary incentives to cooperate.

The paper begins with a review of the core features at base of international cooperation. Following this, section 3 considers the recent international responses and the efforts carried out at the multilateral level and the significant role played by the ICN. It then moves to explore the ICN proposal and the UN mechanism as well as ways to strengthen the ICN framework by incorporating key elements of the UN Set, section F.4.

\section{Features of international cooperation in cartels and barriers against cooperation}

International cooperation in cartel enforcement presents specific features different from other anticompetitive practices such as mergers or unilateral conducts at the international level. There is sufficient evidence of the harmful effects of hard-core cross-border cartels to developing countries and countries in transition since the detection and sanctioning of international cartels in $1990 \mathrm{~s}^{20}$. Due to the intrinsic international nature of cartels, key domestic tools provided by domestic laws such as dawn raids and leniency programmes become insufficient to target cross-border cartels. Classic international instruments such as formal cooperation agreements have proven to be underused due to the diverse legal standing of anti-cartel laws (administrative vs. criminal offences) and the inability of legal treaties to overcome these difficulties. ${ }^{21}$

\subsection{Features of international cooperation in cartels}

Cartels are plain collusion which may be defined as a situation whereby a number of companies agree not to compete in order to increase the combined profits of the whole group. These profits can be achieved through different means but all entail an increase in prices and a reduction in the volume of

\footnotetext{
${ }^{19}$ See Hollman, Hugh, and William E. Kovacic. "The International Competition Network: Its Past, Current, and Future Role." Minnesota Journal of International Law 20 (2011): 274; and www.internationalcompetitionnetwork.org

${ }^{20}$ See Levenstein, M. and Suslow, V. Supra at Note 3

21 Consider the case of Mutual Legal Assistance Treaties (MLATs). http://www.internationalcompetitionnetwork.org/uploads/cartel\%20wg/icn_chapter_on_international_cooperation_and_info rmation_sharing.pdf
} 
traded goods, which would not occur in a situation where companies compete. ${ }^{22}$

Unlike the agreements that involve some form of horizontal integration, cartels do not have, in principle, any kind of productive efficiency advantage that may relate to a better use of resources or costs saving ${ }^{23}$. This is probably why horizontal collusive practices are one of the main focuses of antitrust law around the world. ${ }^{24}$

"There is a large degree of agreement among competition officials on the competition effects of hard-core cartels, such as price fixing, market division, and bid rigging, even if legal approaches vary considerably from one jurisdiction to another. Hard-core cartels once identified are prohibited outright in many countries, without regard to the market power of the participants, their motives, or purported business justifications. ${ }^{25 \prime}$

Since the last decade of the twentieth century until now, many countries have intensified the anticartel policies that seek to prove the existence of covert collusion through obtaining additional direct evidence (sometimes turning them into cases of overt collusion). The most important of these policies is undoubtedly the "leniency program", which consists in giving incentives to enterprises to plead guilty of engaging in collusive behaviour, and to provide evidence to directly prove the occurrence of the conduct in question, thus incriminating other enterprises in the cartel. These incentives generally grant immunity for the denouncing enterprise in the proceedings against the conduct in question, or substantially reduce its sanctions. Usually, these programs are only proposed to the first company in the cartel who confesses its guilt and, sometimes, only when it relates to cartels that are not already being investigated by antitrust agencies. ${ }^{26}$

\subsection{Barriers against cooperation}

Even though mature agencies' willingness to cooperate within the limits of their confidentiality legislation is increasingly often in a globalized economy, legal cultural obstacles related to the

\footnotetext{
22 Griffin, James M. "An inside look at a cartel at work: Common characteristics of international cartels." Review of Industrial Organization (2001): 29-55.

${ }^{23}$ This assertion has its exceptions, just like any rule, at least from a theoretical point of view. The inexistence of competitive equilibrium in markets presenting what is known as "empty core" has led certain authors to argue that collusion is a mechanisms through which markets that would otherwise be in permanent lack of equilibrium (with constant entries and exits of enterprises, bankruptcies, and business restructuring) may achieve a stable industrial structure and may be more efficient from a certain perspective. In this sense, the most important reference is Telser (1987).

${ }^{24}$ See FOX Supra Note 11

${ }^{25}$ NOONA, Chris. "The Emerging principles of International Competition Law". Oxford University Press 2008, page 60.

${ }^{26}$ From an economic point of view, leniency programs are considered to make explicit collusion less profitable, and hence discourage enterprises from establishing cartels. Depending on the situation, it may be better or worse to limit the program to the first company to confess its guilt, or to cases where competition agencies are already monitoring and for which there is other evidence of direct or indirect collusion. In any case, economic literature generally agrees that these programs reduce the number of profitable cartels. On the other hand, leniency programs may also generate detrimental effects such as strengthening subsisting cartels, since they may imply that enterprises use those programs as means to threaten other enterprises in the cartel considering a deviation from the collusive agreement. For a more detailed analysis of all these issues, see Bigoni, Maria, et al. "Fines, leniency, rewards and organized crime: Evidence from antitrust experiments." (2008) and Miller, Nathan H. "Strategic leniency and cartel enforcement." The American Economic Review 99.3 (2009): 750-768.
} 
administrative law principle of "legality" that govern domestic competition law proceedings will hamper cooperation markedly. ${ }^{27}$ Commonly, in civil law jurisdictions, the principle of "legality" reflects that civil servants shall be governed by the assumption that "anything that is not expressly permitted is prohibited." 28 As such, officers would not carry out any informal cooperation activity with foreign counterparts if they are not "expressly" authorised to do so by law. It will require, therefore, changes of the law that will literally mandate that officers should be able to "reach out" to their foreign counterparts in order to get information regarding similar cases being treated abroad. Of course, the latter has not happened. Beyond this barrier, a second one would the so-called "novelty" of cooperation. If a case handler is not going to be criticized for failing to reach out to a foreign counterpart, but risk criticism if he or she does, it is only natural to understand what is going to happen. ${ }^{29} \mathrm{~A}$ third barrier is considered to be "psychological." Consider a new case handler in a new agency not willing to contact mature agencies as there is a natural "human" barrier to be overcome, due to the lack of trust and confidence in presenting a "sound" request of information. In this sense, intangible and often personal incentives might be decisive to pick-up the phone and reach out foreign counterparts. This would be also encouraged if the organizational purpose is endowed and endorsed by a leader within the mature or smaller agency. ${ }^{30}$

\subsection{Incentives for cooperation}

Generally, cooperation between competition agencies is viewed to be driven by the incentives available to the individuals making up such agencies which are regarded as professional incentives. ${ }^{31}$ However, in some occasions, these incentives as they are impacting human activity may be linked to egotistical motives of self-preservation or self-gratification. ${ }^{32}$ In international cooperation merger cases, the parties involved have the incentive to cooperate because the merging companies need to have legal certainty from major jurisdictions, so as to avoid nullifying their merger operations in different markets. Internally, companies and agencies, as organizations, have their own system of incentives and rewards when it comes to cross-border cooperation.

Incentives for cooperation at the level of international cartel investigations can be crystallised in a number of coordination mechanisms carried out by major law enforcers. For instance, in the air cargo cartel, international cooperation at the enforcement stage took place in the form of coordinating

\footnotetext{
${ }^{27}$ Interview with Russell Damtoft, Associate Director of International Affairs, Federal Trade Commission of the United States of America. The interview was conducted in January 2017

${ }^{28}$ See David Dyzenhaus, Murray Hunt \& Michael Taggart (2001) The Principle of Legality in Administrative Law: Internationalisation as Constitutionalisation, Oxford University Commonwealth Law Journal, 1:1, 5-34

${ }^{29}$ See DAMTOFT Supra Note 27.

${ }^{30}$ See Clark, Peter B., and James Q. Wilson. "Incentive systems: A theory of organizations." Administrative science quarterly (1961)

${ }_{31}$ Terhechte, Jörg Philipp. International competition enforcement law between cooperation and convergence. Springer Science \& Business Media, 2011.

${ }^{32}$ See CLARK Supra Note 30: citing Chester Bernard Harvard at p. 129.
} 
international dawn raids by the usual suspects (mature agencies) worldwide ${ }^{33}$, whereby similar powers of investigation, system of internal rewards and even convergent anti-cartel legislations exist.

The conditions under which cooperation can occur vary in detail from society to society. Thus, comparable incentives can sometimes produce dissimilar results in different contexts. The level of maturity of a country's competition culture can likewise affect the applicable incentive system. In particular, countries that have recently adopted competition rules, have young competition authorities, or have very limited competition culture were be unable to take part of international cartel investigations such as the air-cargo cartel. ${ }^{34}$ To illustrate, in relation to the ICN Framework, information solicited from mature jurisdictions by young or small competition agencies were apparently unutilized. In some cases, young competition agencies from developed countries failed to initiate their own domestic cartel investigations as there was no response to their request for information from the world lead competition enforcers. ${ }^{35}$

Based on the foregoing, there is a need to identify the applicable the necessary incentives for all the stakeholders to develop trust in the system and to cooperate. Let us go through the main actor's interests and see ways to induce cooperation.

\section{(1) For mature agencies:}

"The [US] Antitrust Division, like competition authorities around the world, strongly supports improving the ability of governments to share information in the investigation of hard-core cartels. Consumer groups and even some members of the private antitrust bar take a similar position. On the other hand, many business groups, although by no means all, take a different view. They advocate a more cautious approach that creates unreasonable barriers to information sharing in cartel cases; barriers that do not exist when governments exchange information to investigate other financial offenses, such as fraud, tax, or securities violations". ${ }^{36}$

The self-explanatory quote is from a major jurisdiction that treats hard-core cartels as criminal offences. Note, however, that legal standing with respect to criminalization of cartels differs from jurisdiction to jurisdiction ${ }^{37}$. When there are commonalities between the legal standing of the mature agencies, there will be more incentives to cooperate.

\footnotetext{
${ }^{33}$ Bergman, Howard, and D. Daniel Sokol. "The Air Cargo Cartel: Lessons for Compliance." (2014).

${ }^{34}$ CLARK. Supra Note 30 at p. 162.

${ }^{35}$ Interviews made with anonymous referees during January 2017.

${ }^{36}$ Hammond, Scott D. "Dispelling the myths surrounding information sharing." United States Department of Justice, (2004). Available at: https://www.justice.gov/atr/speech/dispelling-myths-surrounding-information-sharing (source visited 16 January 2017)

${ }^{37}$ For a comprehensive assessment of the legal and economic implications of criminalising cartel laws see: Cseres, Katalin J., et al., eds. Criminalization of competition law enforcement: economic and legal implications for the EU member states. Edward Elgar Publishing, 2006.
} 
On a practical level, individuals in more mature agencies may be willing to help their peers out of altruism, but those in case teams are normally too overloaded with work to respond to numerous requests from small or young jurisdictions ${ }^{38}$. Mature agencies would be incentivised to respond to requests for information if they feel and trust that the information shared with the foreign agency would not be misused or leaked to third parties ${ }^{39}$. As more and more small or young agencies are set up, the concern would be how mature agencies would be handling these case-specific requests.

To address the foregoing concern, UNCTAD posed a question as to how general information cooperation can turn into specific-case informal cooperation ${ }^{40}$ and that is where the challenge remains ${ }^{41}$. Of course, “...good will, trust, and a desire to work together..." [as well as] “...understanding of each other's' needs and confidentiality restrictions..." [are] “...the best instruments for cooperation Telephone or e-mail!...." ${ }^{42}$ Obviously, it is not as simple as it reads, otherwise, all competition agencies could have already done it. Verily, other factors must be taken into account. ${ }^{43}$ Popular Myths such as "lack of a formal cooperation mechanism prevents effective cooperation" or "cooperation requires an enforcement mechanism to make it work" or the "cooperation only takes place among developed countries" 44 can be contrasted to the reality whereby indeed "effective cooperation happens every day, with and without a formal mechanism..." and "cooperation requires mutual trust and strong relationships" as well as "cooperation takes place wherever there are enforcement interests in common"45. While this might be true, in particular, as to informal cooperation benefits, it must be noted that enforcement interests of a mature agency and a young competition agency are not often in common ${ }^{46}$.

\footnotetext{
${ }^{38}$ Jensen, Michael C. "Self interest, altruism, incentives, and agency theory." (1994).

${ }^{39}$ Parties that are not part of the process - not entitled to the information as per the relevant legislation - in many cases third party litigants - disclosure to them could harm their leniency program - and most countries have specific laws prohibiting disclosure outside the process for which the info was gathered

${ }^{40}$ Case specific informal cooperation can be possible, if a number of potentially sharable non-confidential information can be exchanged between agencies. These categories of information could be: (1) Existence of investigation; (2) Theories about harm, markets, or remedies; and (3) industry background. See Damtoft, Russell W. "Mechanisms for cooperation: informal cooperation". 14th Session of Intergovernmental Group of Experts (2014). At slide 11. Available at: http://unctad.org/meetings/en/Presentation/CCPB_IGE2014_RTPRESInfCoop_USFTC_en.pdf

${ }^{41}$ UNCTAD "Informal cooperation..." Supra Note 15. Also see US submission on possible approaches to informal cooperation, being: (1) Effective cooperation on the basis of publicly available or non-confidential information; (2) Waivers of confidentiality; (3) Building cooperative relationships; and (4) Deferral to partners in appropriate cases. See DAMTOFT, Supra Note 40.

${ }^{42}$ DAMTOFT Supra Note 40 at slide 14.

${ }^{43}$ In interviews with heads of young and small agencies, it transpired that cooperation with other agencies lies on legal barriers that arise from the distinction between common law and civil law systems as well as top-down policies whereby civil servants might be sanctioned if communications with foreign colleagues are concerned the cases handled, especially if these cases are related to cartel enforcement. The primary source here is anonymous at the request of the interviewees.

${ }^{44}$ DAMTOFT Supra Note 40 at slide 18.

${ }^{45}$ DAMTOFT Supra Note 40 at slide 18

${ }^{46}$ It has been reported that when several Japanese firms fixed the price of automobile parts in multiple jurisdictions and those firms pleaded guilty before US authorities, the Colombian competition authority requested information from these US authorities at the initial stage of investigation so as to effectively establish the case. However, they had difficulty doing so as they hadn't built a close cooperative relationship with the US competition authority. Maria Claudia Martinez Beltran, "INTERNATIONAL CARTEL INVESTIGATION IN THE SIC Investigation Limitations and Possible Future Solutions",
} 


\section{(2) For young and small agencies:}

Although the incentives for young or small agencies are straightforward ${ }^{47}$, somehow, their representatives do not feel comfortable picking up the phone and reaching out to their counterparts abroad. ${ }^{48}$ In some cases, language barriers and cultural differences become limitations. ${ }^{49}$ In most of the cases, however, it is just a matter of willingness and lack of trust and understanding vis-à-vis their counterparts. Furthermore, when they finally decide to cooperate, younger and smaller agencies tend to produce request very broad and vague requests for information which the counterpart agency may find difficult to process, due to, in a number of cases, heavy workload and other priorities. ${ }^{50}$

Cross-border cartels taking place between younger agencies at the regional level may be the focus for these authorities rather than international cartel ones. Consider the fact that international investigations by mature agencies would break up an international cartel. This action would evidently benefit developing countries as well, so the younger/small agency could well conclude that since the problem will be solved, it would best put its scare resources on domestic cartels where there will be no free rider possibility. In those cases, the need for cooperation would exist only if there was some reason the developing country would need to have a separate remedy.

\section{(3) For the parties/companies/lawyers:}

It has been conceived as an ordinary myth that parties would be more in favour of inter-agency information sharing in international merger cases rather than cartel cases. ${ }^{51}$

Incentives for the parties might not be clear and obvious to young/small agencies but reality shows that parties, including international law firms involved in open cartel investigations worldwide, would be happier in many cases if young/small competition agencies could be "briefed" by mature agencies on the general information of the case (without the need to have waivers). The foregoing is considered more efficient compared to the international law firm undertaking this briefing on its own. The briefing that mature agencies can provide to younger

2013. See also Schoneveld, Frank R. "Cartel Sanctions and International Competition Policy: Cross-Border Cooperation and Appropriate Forums for Cooperation." World Competition 26 (2003): 433.

${ }^{47}$ Ramakrishnan, Ram TS, and Anjan V. Thakor. "Cooperation versus competition in agency." Journal of Law, Economics, \& Organization (1991): 248-283.

${ }^{48}$ Interviews with anonymous referees carried out in January 2017.

${ }^{49}$ See CLARK. Supra Note 30

${ }^{50}$ Interviews with anonymous referees carried out in January 2017.

${ }^{51}$ Already by 2003, an impressive list of documented cases of cooperation in mergers were submitted. See Jenny, Frédéric. "International cooperation on competition: myth, reality and perspective." The Antitrust Bulletin 48.4 (2003): 973-1003 at p. 993. See also: Zanettin, Bruno. Cooperation between antitrust agencies at the international level. Bloomsbury Publishing, 2002. 
agencies will simplify procedures and reduce transaction costs, considering that the complexity of procedures for a young agency's interaction with law firms in its local jurisdiction may lead to delay and unnecessary additional hurdles, such as information to be submitted, local formalities, and of course, additional lawyer fees. ${ }^{52}$ As a result, parties should be, in principle, in favour of this cooperation whereby non-confidential information could be shared efficiently between mature and young/small agencies.

Presumably, the incentive for agencies and parties would be to have legal certainty and coherence in the parallel investigations that could be launched, not only by mature agencies, but by small and younger agencies. Of course, willingness to cooperate and trust in the system are prerequisites for all of these to work effectively. In sum, incentives from the three main stakeholders were also reviewed in order to see how these incentives could be induced. The following quote summarises what cooperation is and how it could be triggered.

"Co-operation implies agreement by two or more organizations on a set of rules that will govern their behaviour vis-at-vis one another in such a way that the autonomy of each is respected, an allocation of potential incentives is agreed upon, and the rewards of observing the rules are held to be greater than the rewards of breaking them"53

According to the above, incentives for all should be clearly defined at the outset of the cooperation; otherwise parties would take that sort of cooperation as business as usual. In essence, younger and small competition agencies (the David) attempting to cooperate between other agencies whether they are mature or not, so as to fight the effects of cross-border cartels formed by multinational firms (the Goliaths). Let us now review how the ICN proposal can address some of these problems.

\section{Japan Fair Trade Commission's 2015 proposal to the ICN}

As illustrated, several key efforts characterise the multinational work to fight international cartels. Unfortunately, some of these initiatives have not been successful, such as the enactment of competition provisions in regional trade agreements. Indeed, the implementation of competition provisions in regional trade agreements is full of set-backs for reasons that range from lack of coordination between competition authorities and trade authorities to lack of trust between competition enforcers. ${ }^{54}$ The regional trade agreements often do not include detailed provisions for cooperation between the parties, and are limited to non-confidential information exchange

\footnotetext{
${ }^{52}$ Interview with anonymous referees carried out in January 2017.

${ }^{53}$ CLARK, Supra Note 44

${ }^{54}$ Hilpold, Peter. "Regulating International Competition Issues by Regional Trade Agreements: A Stepping Stone Towards a Plurilateral Trade Agreement?." European Yearbook of International Economic Law 2013. Springer Berlin Heidelberg, 2013. 71-86.
} 
agreements, with a small number including provisions on technical assistance on competition matters. ${ }^{55}$ On the other hand, the enforcement avenues available through international judicial assistance and the unilateral extraterritorial enforcement of national competition law are fraught with jurisdictional, diplomatic drawbacks and practical shortcomings, including problems relating to antitrust investigations, such as serving notice, acquiring information, launching an enquiry, and final enforcement. ${ }^{56}$ As a result, inter-agency cooperation in competition investigations and enforcement by multi-jurisdictional fora are considered to have greater potential than those traditional rules of judicial cooperation amongst courts ${ }^{57}$ and foreign states' amicus curiae participations in mature competition regimes. ${ }^{58}$ International competition law cooperation can provide specific practical advantages such as "...a better use of resources, avoidance of conflicts with other laws and rulings and a more predictable and (cost-) efficient outcome which is beneficial to the business environment...."59 Young and small competition agencies are urged to see alternative tools and procedures to fight against crossborder cartels ${ }^{60}$. For these reasons, in this section, focus is made on the Japan Fair Trade Commission's 2015 proposal to the ICN to foster non-confidential sharable information between competition agencies in the fight against international cartels.

During the Seoul ICN Annual Conference, the ICN members decided to launch the ICN Cartel Working Group with the objective to "... begin discussions on how to cooperate in the fight against cartels and to gauge the scope for convergence across jurisdictions..." 61 Since then, this transgovernment network has facilitated the convergence of practices ${ }^{62}$ when dealing with cartels, and adopted a compilation of investigative approaches used by ICN Members possessing differing levels of experience. ${ }^{63}$ The ICN Anti-Cartel Enforcement Manual (ICN Manual) was conceived as a

\footnotetext{
${ }^{55}$ See Holmes, Trade and Competition in RTA's- A Missed Opportunity? p. 72.

${ }^{56}$ Martyniszyn, Marek. "Discovery and Evidence in Transnational Antitrust Cases: Current Framework and the Way Forward." Browser Download This Paper (2012)

${ }^{57}$ Basedow, Jürgen. "» Competition Policy in a Globalized Economy: from Extraterritorial Application to Harmonization «." The International Handbook of Competition (2004): 321.

${ }^{58}$ See Martyniszyn, Marek. "Foreign States' Amicus Curiae Participation in US Antitrust Cases." The Antitrust Bulletin 61.4 (2016): 611-642.

${ }^{59}$ Demedts, Valerie. "International competition law enforcement: different means, one goal?." COMPETITION LAW REVIEW 8.3 (2012): at page 228.

${ }^{60}$ Consider for instance the recent options submitted which are: (1) recognition of decisions made by agencies or courts in other jurisdictions; (2) one-stop shop models; (3) appointment of one or more lead jurisdiction(s) in cross-border cases; (4) joint investigative teams and cross-appointments; and (5) cooperation at court level. Of course, every single would face difficulties in implementing some of these options. See Capobianco, Antonio, and Aranka Nagy. "Developments in International Enforcement Co-operation in the Competition Field." Journal of European Competition Law \& Practice 7.8 (2016): 566-583.

${ }^{61}$ Roebling, George. "The launch of the new ICN Cartel Working Group." Competition policy newsletter 2 (2004): 28-30.

${ }^{62}$ For a comprehensive assessment of trans-governmental networks, see Slaughter, Anne-Marie. "The real new world order." Foreign affairs (1997): 183-197; and Slaughter, Anne-Marie, and Thomas Hale. "Transgovernmental networks." The handbook of governance (2010): 342-352.

${ }^{63}$ The Manual includes practical discussions and tips based on member agency practices covering the following topics, organised by chapter: searches, raids and inspections, drafting and implementing an effective leniency program, digital evidence gathering, cartel case initiation, investigative strategy, interviewing techniques, case resolution, and cartel awareness, outreach and compliance initiatives. The Manual presents 10 Chapters which are regularly updated by the ICN members. The chapter are on searches, Raids and Inspections (2009); Drafting and Implementing an Effective Leniency
} 
“...living document that may evolve as new techniques, technologies, and approaches are developed and implemented...". ${ }^{64}$ As competition enforcement systems differ across jurisdictions ${ }^{65}$, the ICN Manual does not intend to be a comprehensive guide for the enforcement of laws concerning hardcore cartels. Rather, it is intended to be a reference tool which agencies can use to evaluate and benchmark their own approaches. The ICN Manual provides the most relevant best practices and techniques employed by mature agencies at various stages of anti-cartel enforcement, proven effective and successful by them. Particular attention should be devoted to the chapter on "International Cooperation and Information Sharing" that reviews the main trends and practices of competition agencies regarding the following topics: types of information, ability to share information, tools for international cooperation, and information sharing (informal, formal as well as international organizations and technical assistance work provided), uses of information, challenges and finally examples of cooperation. ${ }^{66}$

Despite all these ICN member efforts, an OECD/ICN survey in 2013 revealed that, within the period of 2007-2012, and out of 57 participating countries that took part of the survey (out of which 31 were OECD members), a majority of non-OECD countries had little experience in international cooperation cases. ${ }^{67}$ Notably, more than half of the respondents of the survey were from Europe, while Africa accounted for $7 \%$, Asia 13\%, and Americas $16 \%$. This fact reflected a partial view of the problem as the vast majority of young and small competition agencies remain in Africa, the Americas, and Asia. ${ }^{68}$

Japan Fair Trade Commission (JFTC), the third earliest competition authority to become fully operational in the world $(1947)^{69}$, became concerned that the vast majority of ICN respondents at the OECD/ICN survey reported that no cooperation has been achieved so far. Thus, in 2015, and as a response to this urgent need to come up with alternative methods to reach the vast majority of young

Policy (2014); Digital Evidence Gathering (2014) ; Cartel Case Initiation (2010) ; Investigative Strategy (2008); Interviewing Techniques (2008); Cartel Case Resolution (2011); Cartel Awareness, Outreach \& Compliance (2012); International Cooperation and Information Sharing (2013); and Relationships between Competition Agencies \& Public Procurement Bodies (2015). See more at: http://www.internationalcompetitionnetwork.org/workinggroups/current/cartel/manual.aspx

${ }^{64}$ The Manual is not the only ICN product adopted by its members. Other products are: Anti-Cartel Templates; Leniency Waiver Templates and Explanatory Note; Building Blocks Report; Cooperation between Competition Agencies in Cartel Investigations; Cartel Settlements Report; 2010 Trends and Developments in Cartel Enforcement; Online Compilation of Cartel Awareness Materials; and Worldwide Leniency Program Links. See at: http://www.internationalcompetitionnetwork.org/working-groups/current/cartel.aspx

${ }^{65}$ CAPOBIANCO, Supra at Note 60.

66 Chapter of the Anti-cartel Enforcement manual. http://www.internationalcompetitionnetwork.org/uploads/cartel\%20wg/icn_chapter_on_international_cooperation_and_info rmation_sharing.pdf

67 OECD/ICN Survey on International Competition Enforcement Co-operation, 2013, available at http://www.oecd.org/competition/oecd-icn-international-cooperation-survey.htm

${ }^{68}$ Own recollection of competition laws enacted and authorities implemented throughout the world and FOX Supra Note 11.

${ }^{69}$ See more in Porter, Michael E., and Mariko Sakakibara. "Competition in Japan." The Journal of Economic Perspectives 18.1 (2004): 27-50. 
and small competition regimes worldwide, Japan submitted a proposal to the ICN to strengthen international cooperation and information sharing amongst ICN members. ${ }^{70}$ The proposal, entitled "Proposal for establishing the ICN Framework for promotion of sharing non-confidential information for Cartel Enforcement" ("ICN framework") comes after 12 years of existence of the Cartel Working group and cooperation is still scarce amongst the increasing number of competition authorities in the world. It is therefore of crucial importance to search for more possibilities to enhance cooperation and realise the very ultimate objectives of the ICN. ${ }^{71}$ The idea behind the ICN Framework is that competition agencies could consider the initiation of an investigation of an international cartel case within their own jurisdictions, based on the exchange of information that the initiating agency (Initiating Agency) could get from a peer agency that has already investigated the same cartel case in its own jurisdiction (Peer Agency) ${ }^{72}$. In the ICN framework, participating agencies could register and indicate liaison officers who will coordinate with each other regarding requests for cooperation. The case team of the Peer Agency can communicate directly with the liaison officer of the Initiating Agency. Overall, the ICN Framework underscores the importance of information sharing between competition agencies to foster coordination in cross-border enforcement and avoid parallel proceedings.

\section{Illustration 1: The JFTC's 2015 proposal to ICN}

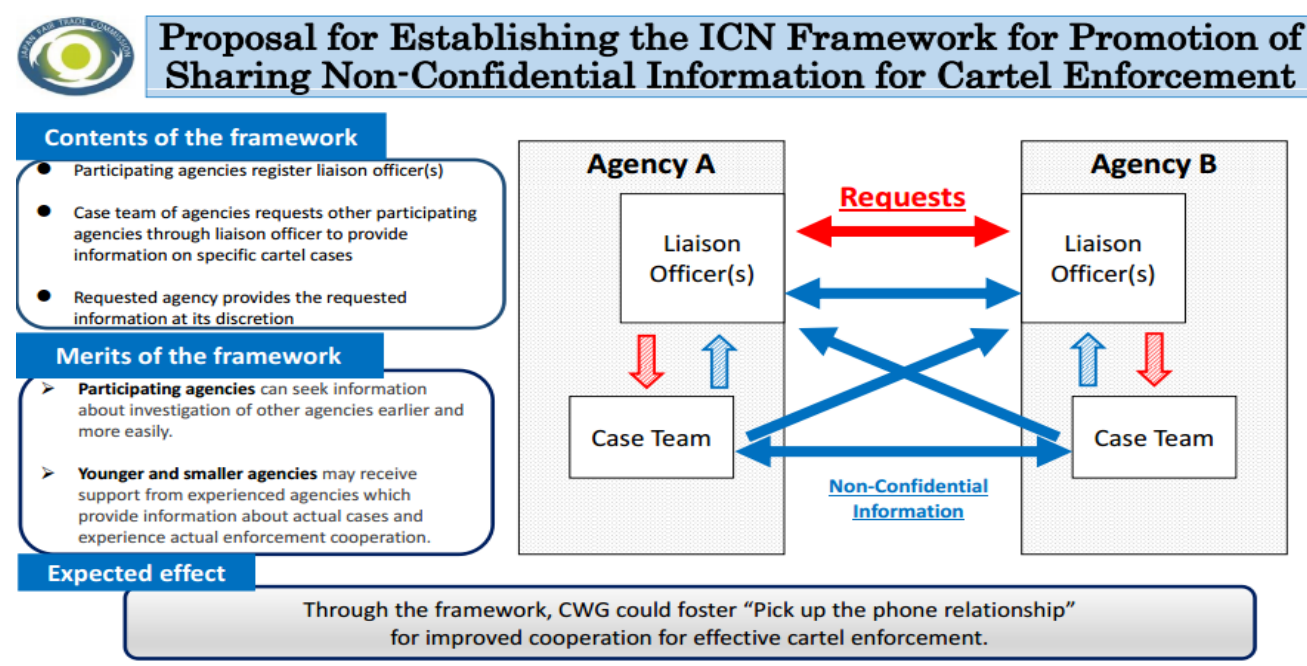

Source: Presentation delivered by Mr. Toshiyuki Nambu Deputy Secretary General International Affairs Japan Fair Trade Commission at the 2014 ICN Cartel Workshop held in Taipei, Taiwan on 2 October $2014 .{ }^{73}$

\footnotetext{
${ }^{70} \mathrm{http}: / /$ www.internationalcompetitionnetwork.org/uploads/library/doc1043.pdf

${ }^{71}$ The proposal was made official by Japan at the 2015 Cartel Workshop, Cartagena, Colombia, October 18 - 21, 2015 and has been adopted by ICN during 2016 onwards. See at http://www.internationalcompetitionnetwork.org/library.aspx? search=\&group=2\&type=0\&workshop=0

${ }^{72}$ See CAPOBIANCO, Supra note 60.

${ }^{73} \mathrm{http}: / /$ www.ftc.gov.tw/icncartel2014/pdf/2014.10.02.\%20Plenary\%20III\%20\%20\%20Toshiyuki\%20Nambu\%20JFTC.pdf (source visited on 12 January 2017).
} 
The ICN Framework, which is being managed by the JFTC, has been operational since January 2016. However, as of January 2017, only 33 ICN member agencies have registered for it. ${ }^{74}$ According to the primary sources consulted, some cooperation cases among younger and smaller agencies have taken place but not made public under the ICN Framework ${ }^{75}$. Some other competition agencies have claimed to have little information about the ICN Framework ${ }^{76}$. The underutilization of the ICN Framework could be attributed to a host of issues, such as the differences between common and civil law jurisdictions when it comes to what public servants are permitted to do or disclose under the principles of administrative law, which could be as an important legal barrier against cooperation. ${ }^{77}$ In addition, there are also difficulties associated with inter-agency evidence sharing in international competition cases ${ }^{78}$ an issue that has been successfully addressed by the European Competition Network under Regulation 1 of $2013 .{ }^{79}$ Finally, factors such as lack of inter-organizational trust ${ }^{80}$ and incentives to cooperate might also be considered in the issue at stake. Other surrounding factors determine whether the ICN framework would be a success or not. ${ }^{81}$

Another limitation of the ICN Framework is that it limits cooperation between agencies that are members of the ICN and have been able to register onto the said framework. Notably, one important economy of the several emerging and large competition agencies, representing economies that greatly influence the world economic and trading order, and which are nowadays shaping important developments in international competition law instruments ${ }^{82}$, is not a member of the $\mathrm{ICN}^{83}$. These agencies have shown the intention to cooperate in investigation efforts. For instance, the Russian Federation, being one of the biggest competition authorities in the world (in terms of number of

\footnotetext{
${ }^{74}$ Interview with anonymous referees carried out in January 2017.

${ }^{75}$ Interviews with anonymous referees carried out in January 2017.

${ }^{76}$ Interview with the President of PROCOMPETENCIA Nicaragua, Dr. Luis Humberto Guzman, carried out in January 2017.

77 See DYZENHAUS Supra Note 28 and Rojo, Margarita Beladíez. "La vinculación de la Administración al Derecho." Revista de administración pública 153 (2000): 315-350 and Llorente, Francisco Rubio. "El principio de legalidad." Revista española de derecho constitucional 13.39 (1993): 9-42..

${ }^{78}$ See Martyniszyn, Marek. "Inter-agency evidence sharing in competition law enforcement." The International Journal of Evidence \& Proof 19.1 (2015): 11-28.

${ }^{79}$ See Capobianco, Antonio. "Information exchange under EC competition law." Common Market L. Rev. 41 (2004): 1247.

${ }^{80}$ A recent empirical research suggested that informal information, although equally determinant for the decision-making process, requires more interorganisational trust to flow and also has more power to create trusting ties. Confidential information, which should not always be exchanged between the entities but does aid the processes, requires much trust in order to flow, and has a strong power to create trust ties, however, when not done with caution it can likewise render a relationship to distrust. See Callens, Marloes. "Interorganisational Information Exchange and Trust: A Case Study of the Flemish Juvenile Justice Chain." (2015).

81 Information-sharing research relate to 3 main levels: (1) interpersonal, (2) intra-organizational; and (3) interorganizational levels. For a review of the literature on information-sharing see: Yang, Tung-Mou, and Terrence A. Maxwell. "Information-sharing in public organizations: A literature review of interpersonal, intra-organizational and interorganizational success factors." Government Information Quarterly 28.2 (2011): 164-175.

${ }^{82}$ Consider for instance the case of BRICS countries. See more in Wilson, Dominic, and Roopa Purushothaman. "Dreaming with BRICs: The path to 2050." Global economics paper 99 (2003): 1. Cf. Armijo, Leslie Elliott. "The BRICs countries (Brazil, Russia, India, and China) as analytical category: mirage or insight?." Asian perspective (2007): 7-42.

${ }^{83}$ See Infra Note 92.
} 
employees ${ }^{84}$ ), has recently proposed to the UN the possibility of strengthening international cooperation in the investigation of cases. ${ }^{85}$

As has been outlined, the future work of the ICN Cartel Working Group is to improve the anti-cartel enforcement across the whole membership of the $\mathrm{ICN}^{86}$. The challenge is to go beyond the usual cooperation among friends and colleagues from the major competition regulators which founded the ICN back in $2002^{87}$, and expand the cooperation to all members of the network and beyond. In sum, it appears that the ICN framework could be an effective mechanism that can be expanded towards other younger and smaller jurisdictions seeking to cooperate and share non-confidential information when investigating cross-border cartels. However, to unleash the full potential of, and improve the trust and confidence in, the ICN Framework, further enhancement and dissemination in multilateral meetings and enhanced transparency between the members are essential.

\section{Weaving the UN Mechanism into the ICN}

ICN's efforts in providing mechanisms for younger and smaller agencies are instrumental but need further reinforcements and incentives for the members to rely on this system. There are three main reasons why a UN mechanism could strengthen the work of the ICN with the particularities and effectiveness of this framework.

(1) Young and small agencies' trust and confidence in UNCTAD's work on Competition law and Policy: Taking into account "UNCTAD's long tradition of representing the interests of developing countries, its legitimacy as part of the U.N. system, and its continued focus on the linkage between competition and development..." ${ }^{88}$ younger and small competition agencies have appreciated the work of the UN in assisting them (through the government) in the enactment of their competition laws and capacity building efforts in strengthening their capacities and institutions to deal with competition law and policy implementation at large. UNCTAD has largely supported the development efforts of countries for a number of

\footnotetext{
${ }^{84}$ In 2004, it was reported to have 1827 employees through the country with 75 regional offices. Presentation of the Federal Antimonopoly Service at the APEC Training Course in August 2005. Available at https://www.jftc.go.jp/eacpf/05/APECTrainingCourseAugust2005/Group2/Efimov_fas.pdf ～(Source visited on 14 January 2017)

${ }^{85}$ See UNCTAD Infra Note 90.

${ }_{86}$ See Cartel Working Group 2015-2018 Work Plan. Available at: http://www.internationalcompetitionnetwork.org/uploads/library/doc1041.pdf (source visited 16 January 2017)

${ }^{87}$ For a complete survey on how international networks respond to international cooperation problems worldwide see Marsden, Philip "Jaw-Jaw not Law-Law - from treaties to meetings: the increasing informality and effectiveness of international cooperation" p. 110 in Ezrachi, Ariel, ed. Research handbook on international competition law. Edward Elgar Publishing, 2012.

${ }^{88}$ Lianos, Ioannis. "The Contribution of the United Nations to the Emergence of Global Antitrust Law." Global Antitrust Law. (2009). P. 42.
} 
historical and political economy considerations, ${ }^{89}$. Therefore, there is an underlying trust that countries, and the young and small agencies representing them, would have with UNCTAD and UN even before the creation of these agencies. Notably, UN instruments related to competition, such as the establishment of Committee III on Restrictive Business Practices (RBPs) at the first session of the preparatory committee of the United Nations Conference on Trade and Employment (UNCTAE) in Church House, Dean's Yard, London in February $1946^{90}$ have long involved several jurisdictions.

(2) Wider membership in the UN: ICN wide membership is an asset ${ }^{91}$ but not all major economies are part of this network ${ }^{92}$. To maximize the opportunities for cooperation, it would be important to look at UN's expanded network under the auspices of UNCTAD, which covers all of the ICN members as well as all major economies which are not affiliated with $\mathrm{ICN}^{93}$. UNCTAD's experience in addressing broad interest across regions with different development and priority needs might be an asset in the growing membership of the ICN so as to avoid fissures throughout the choice of ICN topics to be addressed in its regular meetings. ${ }^{94}$

(3) Additional advocacy activities in the multilateral arena: The ICN Advocacy \& Implementation Network Support Program (AISUP) does valuable work in encouraging ICN member agencies to greater implement ICN work products and promoting more efficient and effective antitrust enforcement worldwide by enhancing convergence and cooperation ${ }^{95}$.

\footnotetext{
${ }^{89}$ Williams, Marc. Third World Cooperation: The Group of 77 in UNCTAD. Burns \& Oates, 1991.

${ }^{90}$ Horna, Pierre "Seventy years of work on Competition Law and Policy in the United Nations (1946-2016)". Available at Sofia Competition Forum Newsletter. Issue 2 (November 2006) p. 23 Available at http://scf.cpc.bg/uploads/data/2016/SCF\%20Newsletter\%202016.pdf (visited on 13 January 2017)

${ }^{91}$ See ICN Member directory at http://www.internationalcompetitionnetwork.org/members/member-directory.aspx (visited on 24 January 2017)

92 "The most notable jurisdiction with a competition law and no representation in the ICN is China, which has three national competition agencies (MOFCOM, NDRC, and SAIC). China participates in the work of the OECD Competition Committee as an observer and is a member of UNCTAD. The Chinese agencies have not discussed their intentions concerning ICN membership". Hollman, Hugh, and William E. Kovacic. "The International Competition Network: Its Past, Current, and Future Role." (2011) p. 20 MINN. J. OF INT'L L. 274 (2011) At p. 275 Note 3. Also available at: https://papers.ssrn.com/sol3/papers.cfm?abstract_id=1967705 (visited on 18 January 2017)

${ }^{93}$ At the latest UNCTAD meeting of October 2016, 22 delegates from China attended the meeting. See at P. 3 of the List of participants of the Intergovernmental Group of Experts on Competition Law and Policy Fifteenth session Geneva, 19-21 October 2016. TD/B/C.I/CLP/INF.6 Available at http://unctad.org/meetings/en/SessionalDocuments/ciclpinf6_en.pdf (visited December 2016)

94 "Assembling a portfolio of projects that suits a network's members arises from expansions of membership. As a competition policy network grows, it may be difficult to pick topics that command broad interest across the network. Fissures may emerge on the basis of regional differences (e.g., competition agencies in the island economies of the Caribbean may have needs that are alien to the landlocked nations of Central Asia) or wide gaps in experience. In addition to, or as a substitute for their participation in the large, multinational networks, some countries might choose to focus resources competition initiatives undertaken in the context of regional networks such as ASEAN, CARICOM, and COMESA... "See HOLLMAN Supra Note 90.

${ }^{95}$ See Activity Report on ICN Advocacy and Implementation Network Support Program (AISUP) 2011-2012.Available at http://www.internationalcompetitionnetwork.org/uploads/library/doc814.pdf (visited on 10 January 2017)
} 
AISUP's efforts can be further enhanced by promoting ICN work products in wider audiences such as the UNCTAD's annual sessions of the UNCTAD Intergovernmental Group of Experts on Competition Law and Policy where competition agencies from the developing world are often present ${ }^{96}$.

In what follows, Section F.4 of the UN Set will be reviewed accordingly.

There has been extensive scholarship on the emergence of the UN Set, which was adopted by the United Nations General Assembly in $1980^{97}$. Among the different matters covered by the UN Set, Section F of the UN Set, related to international measures and voluntary consultations, has been the least explored and discussed ${ }^{98}$. Interestingly, recent expressions call for Section F's potential to be unleashed for the benefit of the vast majority of young and small competition regimes worldwide ${ }^{99}$.

Section F of the UN Set on Competition was originally conceived to address the harmful effects of a cross-border cartel impacting a company seeking to get enforcement actions with the competition agency in its own jurisdiction. ${ }^{100}$ Section F.4 describes a voluntary consultation scheme, which bear similarities to the ones contained by the 1976 OECD Guidelines and the voluntary consultations in the old General Agreement on Tariffs and Trade (GATT). ${ }^{101}$

\section{"...4. Consultations:}

(a) Where a State, particularly of a developing country, believes that a consultation with another State or States is appropriate in regard to an issue concerning control of restrictive business practices, it may request a consultation with those States with a view to finding a mutually acceptable solution. When a consultation is to be held, the States involved may request the SecretaryGeneral of UNCTAD to provide mutually agreed conference facilities for such a consultation;

(b) States should accord full consideration to requests for consultations and, upon agreement as to the subject of and the procedures for such a consultation, the consultation should take place at an appropriate time;

\footnotetext{
${ }^{96}$ See UNCTAD Supra Note 91.

${ }^{97}$ See: Timberg, Sigmund. "Restrictive Business Practices as an Appropriate Subject for United Nations Action." Antitrust Bull. 1 (1955): 409.; Davidow, Joel, and Lisa Chiles. "The United States and the issue of the binding or voluntary nature of international codes of conduct regarding restrictive business practices." The American Journal of International Law 72.2 (1978): 247-271.; Davidow, Joel. "The UNCTAD Restrictive Business Practices Code." The International Lawyer (1979): 587-605.; Kleiner, Christopher. The UN-Set on restrictive business practices: a step towards a new international economic order. 1982; Fikentscher, Wolfgang. "United Nations Codes of Conduct: New Paths in International Law." The American Journal of Comparative Law (1982): 577-604.; and Snell, Steven L. "Controlling Restrictive Business Practices in Global Markets: Reflections on the Concepts of Sovereignty, Fairness, and Comity." Stan. J. Int'l L. 33 (1997): 215.

${ }_{98}$ Initially, UNCTAD was supposed to play a role in dispute settlement but after lively discussions during the December 1979, delegations did not agree to have a binding resolution but a set of principles whereby affected countries would go on consultations with no prior commitment to binding arbitration or conciliation. Benson, Stuart E. "UN Conference on Restrictive Business Practices." The American Journal of International Law 74.2 (1980): 451-453. At p. 452.

${ }^{99}$ In October 2016 at the 15th session of the IGE on Competition Law and Policy, the Russian Delegation to the United Nations submitted a key note speech delivered by the Head of the Federal Antimonopoly Service *FAS* whereby it was mentioned the need to further enhance the usefulness of Section F of the UN Set when it comes to investigation of crossborder competition cases. See UNCTAD "Report of the Intergovernmental Group of Experts on Competition Law and Policy on its fifteenth session”. TD/B/C.I/CLP/40. 23 November 2016. At p. 4
}

${ }^{101}$ Oesterle, Dale A. "United Nations Conference on Restrictive Business Practices." Cornell Int'1 LJ 14 (1981): 1 at p. 44 
(c) If the States involved so agree, a joint report on the consultations and their results should be prepared by the States involved and, if they so wish, with the assistance of the UNCTAD secretariat, and be made available to the Secretary-General of UNCTAD for inclusion in the annual report on restrictive business practices..." 102 “.

According to the above, there are the four key elements for the implementation of this provision: ${ }^{103}$

1. An Issue Concerning the Control of "Restrictive Business Practices": The content of the term restrictive business practice used in Section F4(a) can be found in Section B(i)1 of the UN Set. Restrictive business practices are deemed to include, inter alia, "acts or behavior of enterprises which, through an abuse or acquisition and abuse of a dominant position of market power, limit access to markets or otherwise unduly restrain competition, having or being likely to have adverse effects on international trade". Section D of the UN Set also elaborates on the meaning of "restrictive business practices", particularly Sections D3 and D4, concerning horizontal coordinated conduct between enterprises and conduct abusive of market power, respectively. The list contained in Sections D3 and D4 are non-exhaustive, allowing for the addition of further anti-competitive practices.

2. The Nature of Consultations: Two points can be made with regard to the nature of the consultations. First, it should be emphasized that Consultations under the UN Set are voluntary and States entering negotiations strive to find mutually agreed solutions. ${ }^{104}$ Second, while Sections B and D address the actions of private enterprises, the Consultations are on a "State-to-State" level. This is in line with the idea that Consultations are cooperative in nature and do not directly seek the resolution of a case by a third party. ${ }^{105}$

3. Full Consideration to Consultations Requests and Agreement upon the Proceeding and Substance: While Consultations are voluntary in nature, member States are required to give full consideration to the request and should be encouraged to enter into the proceeding to explore, and if possible reach, mutually agreeable solutions. If a State declines to participate

\footnotetext{
${ }^{102}$ UNITED NATIONS CONFERENCE ON RESTRICTIVE BUSINESS PRACTICES: MULTILATERALLY AGREED EQUITABLE PRINCIPLES FOR THE CONTROL OF RESTRICTIVE BUSINESS PRACTICES.” International Legal Materials, vol. 19, no. 3, 1980, pp. 813-823. www.jstor.org/stable/20692174

${ }^{103}$ See Costa Rica's submission to the Sixth Review Conference of 2010 whereby it was proposed specific modalities for the implementation of the voluntary consultations provided for in Section F (4) of the Set. The proposed modalities included a number of requirements for the application, the envisaged elements to be included in the response of the request and the possible extension of the UNCTAD secretariat's participation. See: UNCTAD Report of the Sixth United Nations Conference to Review All Aspects of the Set of Multilaterally Agreed Equitable Principles and Rules for the Control of Restrictive Business Practices TD/RBP/CONF.7/11. January 2011.

${ }^{104}$ Oesterle, Dale A. "United Nations Conference on Restrictive Business Practices." Cornell Int'l LJ 14 (1981): 1 at p. 43.

105 Brusick, Philippe. "UN Control of Restrictive Business Practices-A Decisive First Step." J. World Trade L. 17 (1983): 337
} 
in the Consultations it would be expected that a reasoned response would be filed to explain its decision. Responses so filed will help to improve future requests and make Consultations more meaningful. Participation of the corresponding States in the proceedings will strengthen consultation as a valid and effective mechanism to address cross-border competition issues. If the States agree to enter into Consultation, they have to agree on the subject and on the procedures of the Consultation. ${ }^{106}$ This makes the procedure more complex as it is one more thing the States have to discuss and agree on. This would also force the States to "reinvent the wheel" for every consultation. Unfortunately, the Sixth UN Conference of 2010 did not specifically instruct UNCTAD to design a procedure for the implementation of the Consultation despite the presentation of the modalities by a member State. ${ }^{107}$

4. Joint report to be prepared by the States with the assistance of UNCTAD:

Once the requesting State and the corresponding State(s) agree to enter into voluntary consultations, they may agree on specific mutually reciprocal solutions and this process could be crystallized in a "joint report". Given the UNCTAD`s expertise and knowledge, the States may also request UNCTAD's assistance in seeking possible agreeable solutions and drafting the report. The conference may want to instruct UNCTAD to bring such assistance when requested by the States.

\subsection{Applying key elements of Section F.4 of the UN Set to reinforce the ICN Framework}

As discussed earlier, section F.4 of the UN Set provides key elements that could facilitate the singingup of new members to this ICN Framework beyond the 33 and thereby the consecutive sharing of

\footnotetext{
${ }^{106}$ Proceedings should be optional to the States entering into consultations. In other words, the States may agree on different procedures. If the States decide to do so, they should still be able to get assistance from UNCTAD. Secondly, the proceeding should be as simple as possible with basic signals to light the path for the States to explore and reach mutually agreeable solutions. The proceeding must be respectful of local laws. States entering into consultations will try to find mutually agreeable solutions that are also consistent with their own local law. Thus, the proceeding should also be respectful of local laws. At the Sixth Review Conference of Nov 2010, UNCTAD member States of the 6th Review Conference in 2010 believed that there were benefits of having a "default" set of procedural rules to implement the consultations pursuant to section F.4. The reasons referred to included (a) the consultations would offer the State another mechanism for cooperation, in addition to formal and informal networks and technical assistance; (b) having such rules would provide predictability for the State members; and (c) UNCTAD could have a role in providing conference facilities, technical assistance and monitoring the agreements, if requested by the parties. Several delegates said that the participation of UNCTAD as an impartial third party would add value to the mechanism and help to legitimize the participation of the States in the consultations before the stakeholders in their own country. While some States may be able to share confidential information, the proceedings must also guarantee such confidentiality. UNCTAD may assist the States in the definition of what information should or should not be shared or in ways to present information while preserving the confidential component, if the States request such assistance. Finally, the proceedings should be to implement Consultations as a cooperation procedure, not as a conflict resolution forum. It also follows that UNCTAD may provide conference facilities and assistance if the States request so, but UNCTAD shall not act as a judge, nor as an arbitrator. See UNCTAD, Supra Note 103.

${ }^{107}$ See Costa Rica submission to the Sixth Review Conference. See UNCTAD Supra Note 76.
} 
non-confidential information. ${ }^{108}$ If the ICN framework is to have the key features of section F.4 of the UN Set on board, younger or smaller agencies would be willing to enter into voluntary consultations, which will have the following stages of cooperation:

Stage 1: In accordance with the ICN framework, participating agencies can register a liaison officer who would lead the communications with the other. The incentive for the mature agency's liaison officer to cooperate would be the possibility of having common enforcement interests with the small or young agency, which is seeking "sharable" information. To abbreviate bureaucracy and to avoid having so many people in the process, it is advisable that the liaison officer and the case team leader be one and the same person. Case team leaders who are fully involved in the case should also be at the forefront of communications with his/her foreign counterpart to prevent delays and errors in communication critical information This change is important to ensure the effectiveness and trust for the tool, as it has been said that: "co-operation is more likely when the organizations involved are few in number and uncertainty can thereby be reduced" 109 . This would be prevent having several officers in the agency knowing sensitive information, addressing concerns that intra-trust agency would be an issue between international officers and case officers protecting their "turfs." 110

Stage 2: Applying Section F of the UN Set presented supra, participating agencies would need to voluntarily agree on the subject and the specific procedures for each consultation. Since the subject matter and the procedures for the consultation is mutually arrived at, the participating competition agencies will have assurance of control over the mechanism. The previous agreement on the subject matter/s and the procedures would also prevent outright refusal to respond or provide information, as, absent any overwhelming concern, it would be unreasonable for an agency to suddenly change its mind as to what it wants to share or discuss. This is a critical stage as ICN framework might need this feature in order to reassure trust on the system based on reciprocity principles between the participating agencies. ${ }^{11}$

While some participating agencies may be able to provide the agency with sharable information, the proceedings must also guarantee such confidentiality. In the absence of an international definition of confidential information, ${ }^{112}$ it is important to set up the specific procedures for such consultation and

\footnotetext{
${ }^{108}$ See_Supra Section on the need to introduce a UN mechanism.

${ }^{109}$ CLARK Supra Note 30.

${ }^{110}$ See CALLENS, Supra note 80 and interviews with anonymous referees conducted in January 2017.

${ }^{111}$ While consultations are voluntary in nature, member States are required to give full consideration to the request and should be encouraged to enter into the proceeding to explore, and if possible reach, mutually agreeable solutions. If a State declines to participate in the Consultations it would be expected that a reasoned response would be filed to explain its decision. Responses so filed will help to improve future requests and make Consultations more meaningful. See Costa Rican contribution proposed modalities for Section F of the UN Set. (October, 2010).

${ }^{112}$ OECD "Best practices for the formal exchange of information between competition authorities in hard-core cartel investigations". Available at http://www.oecd.org/competition/cartels/35590548.pdf (Source visited 28 December 2016)
} 
eventually provide a definition of what information should or should not be shared or in ways to present information while preserving the confidential component, in accordance to their domestic laws. The proceedings should be to implement Consultations as a cooperation procedure, not as a conflict resolution forum as indicated supra.

Stage 3: Once the subject matter and the procedures are established ad-hoc, the lead case team officers can provide information to each other on the following categories of agency sharable information: (1) existence of investigation; (2) theories about harm, markets, or remedies; and (3) industry background. ${ }^{113}$ These three categories do not constitute confidential information, as these were not provided by parties and are not protected by domestic laws. ${ }^{114}$ The ICN framework provides a detailed workflow that could be established.

Stage 4: If the participating agencies agree, the process could be crystallised in a joint report that would track and record the consultations and the outcome of these communications. Even if the consultations do not result to a successful sharing of non-confidential sharable information, the fact that attempts to carry out communications were tracked and recorded could indicate to the ICN members that the system is progressing, and that it could eventually yield concrete results. In addition, the joint report could fuel more discussions about how international cooperation could be approved, by being presented at the annual conferences of the ICN whereby head of agencies meet in closed doors. ${ }^{115}$ After a certain period of time, the joint report could also be submitted as an item to be discussed at the annual meetings of the UNCTAD Intergovernmental Group of Experts on Competition Law and policy. Sharing the experience of the participating agencies could build trust and confidence in the system as the universal UN membership can appreciate these results. ${ }^{116}$ Illustration 2 below suggests the workflow of the 4 stages presented and the key features of this tool.

\section{Illustration 2: Reinforcing the ICN Framework to foster international cooperation in case investigations}

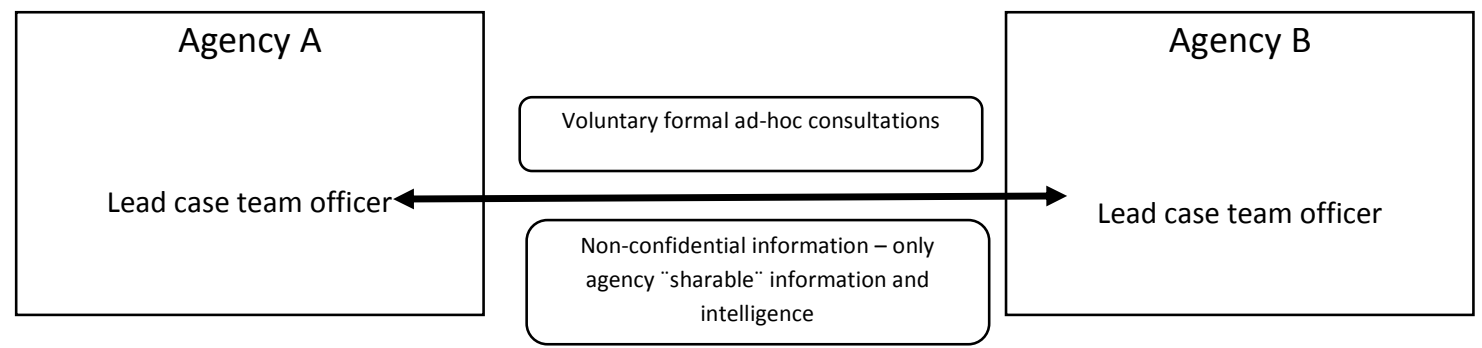

\footnotetext{
${ }^{113}$ DAMTOFT Supra Note 40
}

${ }^{114}$ See MARTYNISZYN Supra note 43

${ }^{115}$ Annual Conference of the International Competition Network in Singapore. Available at: http://www.internationalcompetitionnetwork.org/uploads/library/doc1069.pdf (source visited on 13 January 2017)

${ }^{116}$ See Supra Section related to "The need to introduce a UN mechanism". 
Source: Own elaboration based on the Japan proposal of 2015

Illustration 2 brings the term "voluntary formal ad-hoc consultations" as a result of the insertion of the key features of Section F.4 of the UN Set. This system will build trust and confidence as explained supra in Section II.

In sum, the application of the Consultations contemplated in Section F.4. of the UN Set into the ICN Framework could help to achieve the cooperation required between competition agencies in different countries to fight anticompetitive conducts with international effects ${ }^{117}$. Indeed, the mechanisms provided by the UN could provide additional ways and means to strengthen the ICN existing framework. In particular, they could be helpful in fostering the ICN Framework.

The two systems can nourish each other and the use of provisions from one should not result in friction. One should view it as an effort to use the best from both organs to create a greater and more efficient whole. Beyond the foregoing, there are some caveats that need to be considered as well in the use of this tool:

(1) Entering into consultations with another State would eventually mean that the issue would move from "... a mere legal problem to a more political realm in which the outcome would depend on the relative bargaining power of the two states and the degree to which the two states wish to protect the respective interest of private companies doing business within their borders..." ${ }^{118}$ However, the world has changed since the adoption of the UN Set in 1980 and what we refer to in this essay are key specific elements of Section F.4 that will eventually bring additional positive results of the ICN Framework, as it was proposed by Japan in 2015.

(2) Responses at the regional level to foster competition laws in different regional groupings ${ }^{119}$ also try to address common old problems that the UN Set wished to solve back in1980, but they have been ineffective due to national factors in their implementations. ${ }^{120}$ As many young and small competition regimes are located in developing countries and economies in transition, conventional wisdom suggests that any international cartel regulation would

\footnotetext{
${ }^{117}$ Efforts to disseminate the content and scope of Section F. of the Set have not been sufficient to facilitate the drafting a proceeding for the implementation of the consultations which will give the consultations more predictability and reduce the number of matters the States have to discuss and agree on to enter into consultations. Thus, drafting of such proceedings and a thorough review and discussion seems like a reasonable next step. These efforts however, should not come at the expense of other initiatives to seek cooperation in other ways or to improve the nature and scope of competition provisions in trade agreements.

119 See Chapeyama, Salome. Developing a regional competition regulatory framework in the Southern African Development Community (SADC). Diss. University of the Western Cape, 2015

${ }^{120}$ See also Horna, Pierre M., and Bahri Ozgür Kayalı. "National Implementation of Competition-Related Provisions in Bilateral and Regional Trade Agreements." Implementing CompetitionGRelated Provisions in Regional Trade Agreements: is it possible to obtain development gains? (2007): 21 .
} 
interfere with their domestic economic policies, among other things, including industrial policy. Hence, there has been a historic resistance from the developing world to implement Section F of the UN Set. This has undermined the UN's efforts to have effective international cartel regulation which could eventually mean an increase of the probability of success. ${ }^{121}$

(3) Not having a preexistent commitment for authorities in the respective jurisdictions to cooperate with each other or to jointly carry on the investigation of alleged anti-competitive conducts exacerbates the problem and leaves a large majority of small and young competition regimes with few options to address their problems. Worse, it may lead to using mature competition laws to supplant their own laws in regulate their own markets ${ }^{122}$.

(4) For the analysis of the consultations provided for in Section F.4, the fact that the UN Set constitutes a body of soft law is irrelevant because such consultations are clearly voluntary obviously for the filing participating agency, but also for the requested Agency.

\section{Conclusion: it takes "multi-two to tango"}

In the search of feasible ways to strengthen international cooperation between competition agencies in cartel investigations, one should not forget the essence of cooperation. It takes two (or more) actors to trigger any type of mechanism. Competition agencies are fully aware that cooperation works if there are trust and sufficient incentives to cooperate. The "usual suspects" that often cooperate (i.e., mature agencies that have developed trust among each other over time) do understand that, in an increasingly complex and inter-connected world, young or small competition agencies do play an important role in, and should be incorporated into, the dynamics of cooperation in cross-border enforcement of competition cases. Of course, there is a price to pay. Mature agencies need to find the right incentives to cooperate with young and small agencies. Young agencies, on the other hand, need to realize the benefits of cooperating with mature agencies. Since these young and small competition agencies have learned all the "good" and "bad" lessons of more advanced and mature agencies in the enforcement of their competition laws it is expected that the learning curve would be much shorter and, as a result, the potential benefits and adaption will be realized more quickly.

\footnotetext{
${ }^{121}$ Lee, John Sanghyun. "Legal Status and Historical Background of Cartels in International Law." Strategies to Achieve a Binding International Agreement on Regulating Cartels. Springer Singapore, 2016. 63-143.

${ }^{122}$ For an assessment as to when and why the developed country should take over, in part, regulation of the developing country's market, see: RALF, Supra note 7.
} 
The ICN has done tremendous work in the last 15 years since its started in bringing together best practices of mature agencies in a number of enforcement issues, including cartels. Competition agencies that have recently enacted competition laws have benefited from all of the knowledge and information available at the ICN. In addition, the young and small competition agencies have appreciated the work of the UN and its focal point agency that deals with competition matters, the UNCTAD, in assisting them first (through the government) in the enactment of their competition laws and capacity building efforts in strengthening their capacities and institutions to deal with competition law and policy implementation at large. For a number of historical and political economy considerations, UNCTAD has largely supported the development efforts of countries and therefore there is an underlying trust that countries (young and small agencies) would have with UNCTAD and the UN instruments since 1946 when dealing with anticompetitive practices was actually dealing with "restrictive business practices". ${ }^{123}$

I believe that the ICN will benefit from the underlying trust that agencies have with respect to the UN. With these two organizations at the helm of cooperation, the agencies would be able to "combine" both international tools that would ultimately bring trust and incentives to cooperate, which is essential to boost international cooperation and raise common interests in enforcement between mature and young agencies.

\footnotetext{
${ }^{123}$ UNCTAD "70 years of work on Competition Law and Policy in the United Nations (1946-2016)" Available at
} http://unctad.org/en/pages/newsdetails.aspx? OriginalVersionID=1278 (source visited on 16 January 2017) 